\title{
Manfaat Olesan Madu Pada Penyembuhan Luka Kulit
}

\author{
Arantsa Lomban, ${ }^{1}$ Sonny J. R. Kalangi, ${ }^{2}$ Taufiq F. Pasiak ${ }^{2}$
}

\author{
${ }^{1}$ Program Studi Pendidikan Dokter Fakultas Kedokteran Universitas Sam Ratulangi, \\ Manado, Sulawesi Utara, Indonesia \\ ${ }^{2}$ Bagian Anatomi-Histologi Fakultas Kedokteran Universitas Sam Ratulangi, Manado, \\ Sulawesi Utara, Indonesia \\ Email: arantsalomban@gmail.com
}

\begin{abstract}
The use of honey in wound care has been used since ancient times. Honey has been shown to have antibacterial properties, as well as low $\mathrm{pH}$ levels making environmental conditions unfavorable for bacterial growth. Clinical observations from human trials report that honey helps granulation tissue formation, increases epithelialization, and reduces inflammation which affects the acceleration of wound healing. The aims of this study is to determine the effect of honey toward wound healing. This study is in the form of a literature review. Literature is taken from one database, namely PubMed. The keywords used are honey and wound healing. After being selected by inclusion and exclusion criteria, ten literature will be reviewed. Honey gave good results and affected the healing of skin wounds, including several types of honey that were studied in experimental animals and in experimental people. In conclusion, honey has an effect on healing skin wounds.
\end{abstract}

Key words: Honey, wound healing

\begin{abstract}
Abstrak: Penggunaan madu dalam perawatan luka telah digunakan sejak saat zaman kuno. Madu telah terbukti memiliki sifat antibakteri, juga kadar $\mathrm{pH}$ rendah membuat kondisi lingkungan yang tidak mendukung untuk pertumbuhan bakteri. Pengamatan klinis dari uji coba pada manusia melaporkan bahwa madu membantu pembentukan jaringan granulasi, meningkatkan epitelisasi, dan mengurangi peradangan yang mempengaruhi percepatan penyembuhan luka. Tujuan penelitian ini untuk mengetahui pengaruh madu terhadap penyembuhan luka. Penelitian ini dalam bentuk literature review. Literatur diambil dari satu database yaitu PubMed. Kata kunci yang digunakan yaitu honey and wound healing. Setelah diseleksi dengan kriteria inklusi dan eksklusi didapatkan sepuluh literatur yang akan direview. Madu memberikan hasil yang baik dan berpengaruh terhadap penyembuhan luka kulit, di antaranya ada beberapa jenis madu yang diteliti pada hewan percobaan maupun pada orang coba. Sebagai simpulan, madu mempunyai pengaruh terhadap penyembuhan luka kulit.
\end{abstract}

Kata kunci: Madu, penyembuhan luka

\section{PENDAHULUAN}

Penyembuhan luka merupakan proses fisiologis yang penting untuk menjaga keutuhan kulit pasca trauma, baik karena kecelakaan maupun karena sengaja. ${ }^{1}$ Luka adalah suatu keadaan rusaknya fungsi dan struktur anatomi yang normal, sedangkan untuk menghasilkan perbaikan fungsi dan kontinuitas anatomi harus melewati proses penyembuhan luka yang merupakan proses dinamik kompleks. ${ }^{2}$ Proses penyembuhan luka secara klasik dibagi menjadi empat stadium: hemostasis (detik sampai menit), inflamasi (3-5 hari), proliferasi (4-14 hari), 
dan remodeling (8 hari menjadi 1 tahun). ${ }^{3}$ Terdapat bermacam-macam jenis luka seperti, luka akut (antara lain; luka goresan, luka bakar, trauma, tusukan jarum, dan sayatan bedah yang didapat di tempat perawatan kesehatan) dan luka kronis (ulkus kaki diabetik atau ulkus tekanan). ${ }^{4}$ Kulit manusia terdiri dari tiga lapisan berbeda: epidermis, dermis, dan hipodermis dengan berbagai tingkat spesialisasi dalam setiap lapisan. $^{5}$

Mengonsumsi madu memiliki sejarah yang sangat panjang di kalangan manusia. ${ }^{6}$ Madu juga digunakan di berbagai macam makanan dan minuman sebagai pemanis dan penyedap rasa. Sejak zaman dulu, madu telah dikenal, karena nilai nutrisi dan terapeutiknya, madu diproduksi di seluruh dunia. Produksi madu global kira-kira 1,20 juta ton per tahun. Negara China, Turki, Argentina, Ukraina, Meksiko, dan Amerika Serikat adalah negara yang utama dalam memproduksi madu. Madu biasanya digunakan sebagai agen anti inflamasi, anti oksidan dan antibakteri. ${ }^{7}$

Sejak zaman kuno, seperti yang ditemukan di makam Raja Tut (Abad ke-14 $\mathrm{SM}$ ), madu telah menempati tempat penting di obat tradisional dan sudah disebutsebut sebagai obat produk dalam karya yang tak terhitung jumlahnya. Madu pertama kali disebutkan sebagai pengobatan luka oleh "Papirus Edwin Smith" (2600 $2200 \mathrm{SM})^{8}$

Orang Yunani dan Mesir kuno, menggunakan madu untuk mengobati luka kulit dan luka bakar dengan mengoleskan secara topikal pada kulit. Madu telah diketahui dapat memperbaiki berbagai macam penyakit tetapi fokus tinjauan ini adalah pada sifat terapeutik madu dalam pengobatan luka pada kulit. Pengobatan tradisional di banyak negara di dunia menggambarkan madu bermanfaat dalam pengobatan berbagai gangguan kulit. Dalam tradisi Malaysia, madu digunakan untuk mengobati furunkel, bisul, luka diabetes dan luka bakar. Obat tradisional Persia mendokumentasikan madu efektif dalam pengobatan luka, eksim, dan peradangan. Dalam pengobatan Ayurveda, obat tradisional asli India, madu digunakan untuk mengobati luka, eksim, dermatitis, luka bakar, penyakit kulit, dan gangren Fournier. Di Burkina Faso, Afrika, telah dilaporkan bahwa masyarakat adat menggunakan madu sebagai bahan pembersih kulit dan sebagai pengobatan ruam campak. Penggunaan madu dalam pengobatan tradisional masih cukup signifikan hingga saat ini, terutama mengingat fakta bahwa sebagian besar penduduk negara berkembang saat ini mengandalkan obatobatan asli sebagai sumber perawatan kesehatan primer. Madu juga telah banyak digunakan sebagai bahan dalam produk kosmetik perawatan kulit baik di masa lalu maupun sekarang. ${ }^{9}$

Kemampuan penyembuhan kulit dari madu telah dikaitkan dengan sifat antimikroba, kemampuannya untuk memodulasi sistem kekebalan kulit dan meningkatkan perbaikan jaringan. Ulasan ini mengeksplorasi penelitian klinis dan ilmiah yang menyelidiki khasiat madu dalam pengobatan luka dan berbagai kelainan kulit lainnya. Tujuan utamanya adalah menggunakan literatur ilmiah untuk mengevaluasi potensi kemanjuran madu dalam pengobatan berbagai gangguan dermatologis. ${ }^{9}$

\section{METODE PENELITIAN}

Metode penelitian ini berbentuk literature review. Pencarian data pada penelitian ini menggunakan satu database yaitu PubMed. Kata kunci yang digunakan yaitu honey and wound healing. Berdasarkan hasil pencarian literature pada database tersebut, peneliti menemukan artikel sebanyak 434 menggunakan PubMed $(n=10)$. Selanjutnya, hasil pencarian yang didapatkan dilakukan skrining berdasarkan ketersediaan fulltext lalu didapatkan sebanyak $(n=40)$. Lalu, sebanyak 30 artikel di ekslusi karena tidak sesuai dengan kriteria inklusi dan eksulsi dan di dapatkan $(n=10)$.

\section{HASIL PENELITIAN}

Berdasarkan hasil seleksi literatur didapatkan sembilan penelitian dengan metode experimental, dan satu penelitian review (Tabel 1). 
Tabel 1. Ringkasan artikel hasil penelitian

\begin{tabular}{|c|c|c|c|}
\hline $\begin{array}{l}\text { Penulis/ } \\
\text { Tahun/ } \\
\text { Lokasi }\end{array}$ & $\begin{array}{l}\text { Metode } \\
\text { Penelitian/ } \\
\text { Populasi }\end{array}$ & Intervensi & Hasil Penelitian \\
\hline $\begin{array}{l}\text { Febriyenti, } \\
\text { et al } \\
(2019) / \\
\text { Padang }\end{array}$ & $\begin{array}{l}\text { Experimental/ } \\
24 \text { ekor tikus } \\
\text { betina }\end{array}$ & $\begin{array}{l}\text { Empat kelompok: } \\
\text { 1. dengan pengobatan honey } \\
\text { gel, } \\
\text { 2. dengan pengobatan } \\
\text { honey film, } \\
\text { 3. kelompok tanpa } \\
\text { pengobatan, } \\
\text { 4. dengan pengobatan } \\
\text { marketed product B }\end{array}$ & $\begin{array}{l}\text { Penelitian ini menunjukan persentase } \\
\text { penutupan luka pada hari ke 1-13 di- } \\
\text { dapatkan hasil bahwa pada kelompok } \\
\text { uji (honey gel dan honey film) mem- } \\
\text { punyai pengaruh yang signifikan ter- } \\
\text { hadap luas luka dengan hasil 0,014 (P } \\
<0,05 \text { ). Fase inflamasi telah terjadi pada } \\
\text { hari ke 0-5 yang ditandai dengan } \\
\text { inflamasi pada luka. Pada fase ini ke- } \\
\text { lompok honey film mengalami persen- } \\
\text { tase penutupan luka yang lebih tinggi } \\
\text { dibandingkan dengan kelompok lainnya } \\
\text { (10,47\% } \pm 4,38 \text { ). Selanjutnya fase } \\
\text { proliferasi kelompok tanpa pemberian } \\
\text { memiliki persentase ke-sembuhan ter- } \\
\text { tinggi dibandingkan kelompok lain } \\
\text { seperti ter-lihat pada hari ke } 21 \text { ( } 81,78 \% \\
\pm 9,47 \text { ). Fase terakhir adalah fase } \\
\text { pematangan yang berlangsung dari hari } \\
\text { ke } 21 \text { hingga luka sembuh. }\end{array}$ \\
\hline Kotian & Experimental/ & Tujuh kelompok & Hasil penelitian ini fase penutupan luka \\
\hline $\begin{array}{l}\text { Sushma, } \\
\text { et al } \\
(2018) / \\
\text { India }\end{array}$ & $\begin{array}{l}\text { Wistar albino } \\
\text { dewasa betina } \\
\text { dan jantan. }\end{array}$ & $\begin{array}{l}\text { 1. Tanpa pemberian (kontrol) } \\
\text { 2. Kelompok Madu, } \\
\text { 3. Kelompok Ghee, } \\
\text { 4. Kelompok GG } \\
\text { (Glycyrrhiza Glabra), } \\
\text { 5. Kelompok NI (Nerium } \\
\text { Indicum), } \\
\text { 6. Kelompok H+G } \\
\text { (honey+ghee), } \\
\text { 7. Kombinasi semua } \\
\text { kelompok (Tot) }\end{array}$ & $\begin{array}{l}\text { lebih baik pada semua kelompok kecua- } \\
\text { li kelompok kontrol. Kelompok kombi- } \\
\text { nasi menunjukan peningkatan yang sig- } \\
\text { nifikan pada penutupan luka dari hari } \\
\text { ke-2 sampai hari ke-16 dan pada kelom- } \\
\text { pok Honey + Ghee dari hari ke-6 sam- } \\
\text { pai ke-16 dibandingkan dengan kelom- } \\
\text { pok kontrol. }{ }^{11}\end{array}$ \\
\hline $\begin{array}{l}\text { Paolo } \\
\text { Governa, } \\
\text { et al } \\
(2019) / \\
\text { Italy }\end{array}$ & $\begin{array}{l}\text { Experimental/ } \\
\text { Pasien ulkus } \\
\text { kaki diabetik }\end{array}$ & $\begin{array}{l}\text { Lima kelompok: } \\
\text { BL1H (acacia, lime, heather, } \\
\text { chestnut,citrus fruits) } \\
\text { BL2H (wild fennel, acacia, } \\
\text { thistle rosemary, clover, } \\
\text { citrus, almond, cherry) } \\
\text { BL3H (chestnut honey) } \\
\text { BLH4 (acacia honey) } \\
\text { BL5H (orange honey) }\end{array}$ & $\begin{array}{l}\text { Evaluasi aktivitas penyembuhan luka } \\
\text { madu Calabrian menunjukkan hasil } \\
\text { yang baik performanya terutama untuk } \\
\text { BL1E (madu multifloral dari pantai } \\
\text { Tyrrenian), mampu membantu pe- } \\
\text { nyembuhan luka pada setiap konsen- } \\
\text { trasi yang diuji, dibandingkan dengan } \\
\text { kontrol. }{ }^{12}\end{array}$ \\
\hline $\begin{array}{l}\text { Raman } \\
\text { Malhotra, } \\
\text { et al } \\
(2016) / \\
\text { Inggris }\end{array}$ & $\begin{array}{l}\text { Experimental/ } \\
27 \text { pasien } \\
\text { mengoleskan } \\
\text { madu di } \\
\text { kanan \& } 19 \text { di } \\
\text { kiri. }\end{array}$ & $\begin{array}{l}\text { Pasien diinstruksikan untuk } \\
\text { mengoleskan madu Manuka } \\
\text { dua kali sehari dan } \\
\text { mengoleskan Vaseline } 4 \\
\text { kali sehari ke kedua sisi } \\
\text { selama } 6 \text { minggu. }\end{array}$ & $\begin{array}{l}\text { Pada } 4 \text { bulan, skala penilaian bekas luka } \\
\text { tidak menunjukkan perbedaan; namun, } \\
\text { pasien melaporkan nyeri bekas luka } \\
\text { lebih sedikit pada sisi yang diobati } \\
\text { dengan Manuka daripada kontrol. } \\
\text { Sebanyak } 31 \text { dari } 46 \text { pasien percaya } \\
\text { bahwa bekas luka serupa di kedua sisi, } \\
11 \text { lebih memilih sisi yang diobati } \\
\text { dengan madu, dan } 4 \text { lebih memilih } \\
\text { kontrol. }{ }^{13}\end{array}$ \\
\hline
\end{tabular}


Sambungan Tabel 1. Ringkasan artikel hasil penelitian

\begin{tabular}{lll}
\hline $\begin{array}{l}\text { Penulis/ } \\
\text { Tahun/ } \\
\text { Lokasi }\end{array}$ & $\begin{array}{l}\text { Metode } \\
\text { Penelitian/ }\end{array}$ & \multicolumn{1}{c}{ Intervensi } \\
Populasi & \\
\hline Peiman & Experimental/ & Luka yang dibalut biasa \\
Goharshenasan & Pasien yang & dengan \\
et al $(2015) /$ & menjalani & Luka yang dibalut dengan \\
Iran & operasi & madu \\
& plastik. &
\end{tabular}

Reham F. El- Experimental/ Empat kelompok :

Kased, et al 10 tikus 1 . Kelompok F (Madu 75\%

(2017)/

Inggris
Seyed

Mohammad

Reza Javadi, et all (2018)/

Iran

$\begin{array}{lll}\text { Nasrin } & \text { Experimental/ } & \text { Dua kelompok: } \\ \text { Takzaree, et al } & \text { 54 wistar } & \text { 1. Kelompok kontrol tanpa } \\ (2017) / & \text { jantan } & \text { perlakuan, } \\ \text { Iran } & \text { dewasa } & \text { 2. Kelompok experimental }\end{array}$

Experimental/ Lima kelompok:

50 ekor 1.Kelompok kontrol

wistar (pemberian lanolin topikal harian),

2.kelompok madu,

3.kelompok N. Sativa (minyak biji),

4.kelompok campuran madu dan N. Sativa (1:1),

5.kelompok phenytoin cream

Hasil penelitian ini menunjukan pada kelompok eksperimen, penyembuhan luka dari hari ketiga sampai hari ke14 pengobatan dengan madu secara signifikan lebih baik secara persentase dibandingkan dengan kelompok kontrol $(\mathrm{P}<0,05)$. Pada pemeriksaan mikroskopis jumlah fibroblas, makrofag, neutrofil dan serat kolagen pada kelompok eksperimen dan kelompok kontrol memiliki perbedaan yang signifikan. Pada kelompok percobaan madu dua kali sehari, serat kolagen dan jumlah fibroblast lebih banyak daripada kelompok kontrol. ${ }^{17}$ 
Sambungan Tabel 1. Ringkasan artikel hasil penelitian

\begin{tabular}{|c|c|c|c|}
\hline $\begin{array}{l}\text { Penulis/ } \\
\text { Tahun/ } \\
\text { Lokasi }\end{array}$ & $\begin{array}{l}\text { Metode } \\
\text { Penelitian/ } \\
\text { Populasi }\end{array}$ & Intervensi & Hasil Penelitian \\
\hline $\begin{array}{l}\text { Turgut } \\
\text { Deniz, et al } \\
\text { (2018)/ } \\
\text { Turkey }\end{array}$ & $\begin{array}{l}\text { Experimental/ } \\
\text { Wistar albino } \\
\text { jantan } \\
\text { dengan berat } \\
\text { rata-rata } 350- \\
450 \mathrm{~g}\end{array}$ & $\begin{array}{l}\text { Empat kelompok: } \\
\text { 1. Kelompok MH (mad } \\
\text { honey), } \\
\text { 2. Kelompok BH (blossom } \\
\text { honey), } \\
\text { 3. Kelompok N } \\
\text { (nitrofurazone), } \\
\text { 4. Kelompok C: kelompok } \\
\text { yang tidak menerima } \\
\text { pengobatan (kelompok } \\
\text { kontrol). }\end{array}$ & $\begin{array}{l}\text { Pada penelitian ini, di lakukan perla- } \\
\text { kuan berbeda yang diterapkan pada } \\
\text { model luka yang terinfeksi kemudian } \\
\text { dievaluasi dengan kadar Hydroxypro- } \\
\text { line levels (HP), Tensile strength } \\
\text { (TS), dan Intensity levels (tampilan } \\
\text { makroskopis). Hasil pada kadar HP } \\
\text { terjadi peningkatan kadar HP antara } \\
\text { hari ke-7 sampai hari ke-14 secara } \\
\text { signifikan lebih tinggi pada kelompok } \\
\text { MH dan N dibandingkan pada kelom- } \\
\text { pok lain. }{ }^{18}\end{array}$ \\
\hline $\begin{array}{l}\text { Benjamin A. } \\
\text { Minden- } \\
\text { Birkenmaier, } \\
\text { et al } \\
(2018)\end{array}$ & Review & - & $\begin{array}{l}\text { Bukti menunjukkan bahwa madu, } \\
\text { khususnya madu Manuka, dapat } \\
\text { menghilangkan bakteri, mengatasi } \\
\text { peradangan kronis, dan mempercepat } \\
\text { penyembuhan luka. }{ }^{19}\end{array}$ \\
\hline
\end{tabular}

\section{BAHASAN}

Berdasarkan hasil penelitian dari literatur-literatur yang direview, madu memiliki pengaruh terhadap penyembuhan pada luka kulit. Penelitian pada tahun 2019 menjelaskan bahwa pengaruh honey gel memiliki efektivitas yang lebih besar untuk mempercepat penyembuhan luka bakar dan luka sayatan jika dibandingkan dengan kelompok yang tidak diberi pengobatan (kontrol negatif). ${ }^{10}$ Selanjutnya penelitian tahun 2018 menjelaskan dalam beberapa tahun terakhir, diyakini bahwa pengobatan tradisional memiliki lebih banyak manfaat terapeutik daripada obat allopathic dalam perawatan luka. Pengobatan tradisional seperti madu, ghee, GG, dan NI dikenal dengan ekstraknya yang memiliki kemampuan penyembuhan luka dalam metode pengobatan Ayurveda dan Folk Medicine. Hasil dari penelitian ini dalam fase epitelialisasi proses penyembuhan baik pada semua kelompok, namun diantara semua kelompok yang menunjukan hasil paling baik adalah kelompok kombinasi (Tot). ${ }^{11}$

Di antara lima madu yang diuji menenjukan hasil hanya BL1 dan BL5 yang mampu meningkatkan kecepatan penyembuhan luka setelah enam jam perawatan, dibandingkan dengan kelompok tanpa pemberian. ${ }^{12}$ Penelitan selanjutnya, memberikan bukti bahwa madu Manuka, dapat menghilangkan bakteri, mengatasi peradangan kronis, dan mempercepat penyembuhan luka efek madu Manuka terhadap segi hasil estetika dan menunjukan penyembuhan pada sayatan blepharoplasty kelopak mata atas. Bekas luka kelopak mata atas yang dirawat dengan atau tanpa madu Manuka sembuh dengan sangat baik, tanpa perbedaan yang signifikan jika dinilai dengan skala penilaian bekas luka yang telah divalidasi. Namun, beberapa manfaat subjektif ringan mungkin ada pada periode pasca operasi awal. ${ }^{13,19}$

Penelitian selanjutnya menunjukan hasil penyembuhan luka dari segi estetika juga dengan menggunakan madu. ${ }^{14}$ Menurut penelitian pada tahun 2017, hasil dari pengobatan menunjukkan bahwa madu berperan positif dalam penyembuhan luka. Pembalut luka hidrogel yang telah disiapkan yang mengandung $75 \%$ madu, berfungsi sebagai penutup tetapi juga untuk memberikan lingkungan yang bersih dan lembab untuk penyembuhan luka secara langsung berkontribusi juga pada peningkatan rege- 
nerasi dan pemulihan jaringan. Selanjutnya dalam suatu penelitian kelompok campuran madu dan minyak biji N. sativa menunjukkan hasil signifikan terbaik dibandingkan dengan semua kelompok (kelompok kontrol, kelompok madu dan kelompok $\mathrm{N}$. Sativa) dalam penyembuhan luka. ${ }^{15}$

Suatu penelitian pada tahun 2017 menunjukan bahwa laju penyembuhan luka pada kelompok eksperimen kedua yang dilakukan pemberian madu dua kali sehari hasilnya secara signifikan lebih tinggi. Kelompok eksperimen dengan pemberian madu secara lokal dua kali sehari meningkatkan proses penyembuhan, mempersingkat fase inflamasi, meningkatan jaringan granulasi, angiogenesis dan fase proliferasi awal serta fase remodeling dan akhirnya terjadi penyembuhan luka yang lebih cepat. ${ }^{17}$ Selanjutnya dalam penelitian tahun 2018 menunjukan hasil yang di evaluasi menggunakan analisis kadar HP, TS, dan intensitas (tampilan makroskopis). Diperoleh bahwa efek pengobatan dengan kelompok MH (nad honey) serupa dan bahkan lebih unggul dari perlakuan pada kelompok $\mathrm{N}$ (Nitrofurazone) dan $\mathrm{BH}$ (blossom honey) standar. Dengan demikian pemberian madu sebagai pengobatan dalam proses penyembuhan luka yang terinfeksi pada hewan percobaan ini mendatangkan hasil yang sukses. Secara khusus, mad honey sama efektifnya dalam penyembuhan luka seperti nitrofurazone. ${ }^{18}$

\section{SIMPULAN}

Penggunaan madu olesan bermanfaat pada proses penyembuhan luka kulit, karena pemberian madu meningkatkan proses granulasi dan epitelisasi, mengurangi jumlah eksudat, dan sterilisasi luka dari mikroba, juga keasaman dan osmolaritas dari madu memainkan peran penting. Selain kandungan nutrisinya yang berharga, madu memiliki aktivitas antiinflamasi dan antioksidan yang menjadikannya bahan alami yang cocok untuk penyembuhan luka.

\section{Konflik Kepentingan}

Penulis menyatakan tidak terdapat konflik kepentingan dalam studi ini.

\section{DAFTAR PUSTAKA}

1. Wang $\mathrm{P}$, Huang $\mathrm{B}$, Horng $\mathrm{H}$, Yeh $\mathrm{C}$. ScienceDirect Wound healing. J Chinese Med Assoc. 2018;81(2): 94-101.

2. Kalangi SJR. Khasiat Madu Pada Penyembuhan Luka Kulit. J Biomedik. 2013;4(3):8-11.

3. Song JJ, Salcido R. Use of honey in wound care: an update. Adv Skin Wound Care. 2011;24(1):40-44.

4. Clark M, Adcock L. Honey for Wound Management: A Review of Clinical Effectiveness and Guidelines. Canadian Agency for Drugs and Technologies in Health. 2018 Nov 6:1-34. Available from: https://www.ncbi.nlm.nih.gov/boo ks/NBK538361/

5. Wong $\mathrm{R}$, Geyer S, Weninger $\mathrm{W}$, Guimberteau JC, Wong JK. The dynamic anatomy and patterning of skin. Exp Dermatol. 2016; 25(2):92-98.

6. Shan Y. Medicinal honey in clinical practice: Viable alternative or useful adjunct in wound care management?. Br J Nurs. 2019; 28 (12):S23-S30.

7. Meo SA, Al-Asiri SA, Mahesar AL, Ansari MJ. Role of honey in modern medicine. Saudi J Biol Sci. 2017;24(5):975-978.

8. Vandamme L, Heyneman A, Hoeksema $\mathrm{H}$, Verbelen J, Monstrey S. Honey in modern wound care: A systematic review. Burns. 2013; 39(8):1514-1525.

9. McLoone P, Oluwadun A, Warnock M, Fyfe L. Honey: A Therapeutic Agent for Disorders of the Skin. Cent Asian J Glob Heal. 2016; $5(1): 241$.

10. Febriyenti F, Lucida H, Almahdy A, Alfikriyah I, Hanif M. Woundhealing effect of honey gel and 
film. J Pharm Bioallied Sci. 2019;11(2):176-80.

11. Kotian S, Sushma K, Kumar B, Pai S, Nayak J, Souza A, et al. The Role of Natural Medicines on Wound Healing: A Biomechanical, Histological, Biochemical and Molecular Study. Ethiop J Health Sci. 2018:28(6):759-70.

12. Governa P, Carullo G, Biagi M, Rago $\mathrm{V}$, Aiello F. Evaluation of the In Vitro Wound-Healing Activity of Calabrian Honeys. Antioxidants (Basel). 2019;8(2):36

13. Litwin A, Ophth FRC, Sagili S, Ophth FRC. Effect of Manuka Honey on Eyelid Wound Healing: A Randomized Controlled Trial. Ophthalmic Plast Reconstr Surg. 2017;33(4):268-72.

14. Division RS. Topical Application of Honey on Surgical Wounds: A Randomized Clinical Trial. Forsch Komplemented. 2016; 23(1):12-5

15. El-Kased RF, Amer RI, Attia D, Elmazar MM. Honey-based hydrogel: In vitro and comparative in vivo evaluation for burn wound healing. Sci Rep. 2017;7(1):1-11.

16. Mohammad S, Javadi R, Hashemi M, Sharifi A, Makarchian HR. Synergistic effect of honey and Nigella sativa on wound. Acta Cir Bras. 2018; 33(6): 518-523.

17. Takzaree N, Hassanzadeh G, Rouini MR. Evaluation of the Effects of Local Application of Thyme Honey in Open Cutaneous Wound Healing. Iran J Public Health. 2017;46(4):545-51.

18. Eroglu O, Deniz T, Kisa U, Comu FM, Kaygusuz S, Murat O. The effect of different types of honey on healing infected wounds. J Wound Care; 2018: 27(Sup10):S18-S25.

19. Minden-Birkenmaier BA, Bowlin GL. Honey-based templates in wound healing and tissue engineering. Bioengineering (Basel). 2018;5(2): 46 